\title{
Analisis Proses Komunikasi Interpersonal Mahasiswa Kelas Produksi Film Dokumenter saat Brainstorming Ide dan Pembuatan Karya Film
}

\author{
Freddy Yusanto \\ Program Studi IImu Komunikasi Universitas Telkom \\ Email: fredyusanto@gmail.com
}

\begin{abstract}
ABSTRAK
Penelitian ini bertujuan untuk menemukan cara dan memahami proses brainstorming ide dan proses pembuatan karya selama satu semester. Dalam hal ini, brainstorming ide dan proses pembuatan film merupakan kegiatan yang harus dilakukan dengan memperhatikan substansi pesan dan cara penyampaiannya kepada audiens. Penelitian ini menggunakan metode kualitatif. Teknik pengumpulan data dilakukan dengan observasi lapangan dan wawancara mendalam. Hasil penelitian menunjukkan bahwa pembuat film dituntut agar memiliki kemampuan atau skill di berbagai bidang mulai dari kemampuan nonteknis hingga kemampuan teknis. Tuntutan kemampuan pada berbagai bidang inilah yang harus diperhatikan dosen pengampu mata kuliah pada waktu membagi kelompok. Sementara itu, brainstorming ide dan proses pembuatan film merupakan kegiatan yang harus diperhitungkan dan dilaksanakan dengan penuh kehati-hatian.
\end{abstract}

Kata Kunci: Komunikasi interpersonal, self-disclosure, produksi film dokumenter

\section{ABSTRACT}

This study aims to find ways and understand the brainstorming process of ideas and the process of making works for one semester. In this case, brainstorming ideas and filmmaking process is an activity that must be done with attention to the substance of the message and how to deliver it to the audience. This study used qualitative method. The data collection techniques were conducted with field observation and in-depth interviews. The results of this study shows that filmmakers are required to have the ability or skills in various fields ranging from nontechnical ability to technical ability. The demands of this various ability in various fields should be considered by lecturers at the time to divide the group. Meanwhile, brainstorming ideas and filmmaking processes are activities that must be carefully calculated and carried out.

Keywords: Interpersonal communication, self-disclosure, documentary film production

\section{PENDAHULUAN}

Proses pembuatan film sebagai tugas akhir (TA) mahasiswa program studi Ilmu Komunikasi dengan peminatan Broadcasting, sering kali terfokus pada persoalan teknis yang harus dihadapi di lapangan dan laboratorium editing. Hal-hal lainnya, seperti substansi dari TA dan penyampaian pesan yang ingin disampaikan kepada audiens tidak tertuang atau tersampaikan dengan baik. Akibatnya, hasil TA tidak maksimal. Padahal, brainstorming ide dan proses pembuatan film menjadi sebuah kegiatan yang harus diperhitungkan dan dilaksanakan dengan penuh kehati-hatian.

Citation : Yusanto, Freddy. (2018). "Analisis Proses Komunikasi Interpersonal Mahasiswa Kelas Produksi Film Dokumenter saat Brainstorming Ide dan Pembuatan Karya Film". Nyimak Journal of Communication, 2(1): 71-79. 
Bagaimanapun juga, kualitas atau kedalaman dari sebuah karya tercermin dari sukses atau tidaknya proses tersebut. Apabila dikerjakan dengan terburu-buru maka film yang dihasilkan akan terasa tidak nyambung, tidak sesuai dengan judul atau konteks, dan lainlain. Sebab itu, untuk mengetahui proses brainstorming ide dan proses pembuatan karya film, perlu diadakan sebuah penelitian komprehensif pada kelas Produksi Film Dokumenter (Semester Ganjil 2017-2018) untuk dapat memahami proses brainstorming dan proses pembuatan karya film.

Dengan memahami proses brainstorming ide dan proses pembuatan karya film, maka mahasiswa dan dosen program studi Ilmu Komunikasi yang mengikuti dan bertanggung jawab terhadap kelas Produksi Film Dokumenter dapat melihat pola komunikasi interpersonal yang paling cocok di dalam kegiatan brainstorming dan pembuatan karya (film). Bagaimanapun juga, pola komunikasi interpersonal yang cocok dapat meningkatkan baik pemahaman terhadap substansi pesan yang ingin disampaikan maupun memberi motivasi terhadap mahasiswa dalam proses pembuatan karya film (Abubakar, 2015; Jonathan, 2014; Kamaruzzaman, 2016; Prasetyo \& Yuniati, 2014; Pratiwi \& Wiyanti, 2017; Purnomo dan Harmiyanto, 2016; Pratiwi \& Sukma, 2013; Siska dan Purnamaningsih, 2003; Siburian, 2014).

\section{METODE PENELITIAN}

Dalam penelitian ini, observasi dilakukan dalam kelas produksi film dokumenter selama tujuh pertemuan, dimulai dari pertemuan ke-3 (16 November 2017) hingga pertemuan ke-9 (28 September 2017). Kelas dibagi menjadi 6 kelompok di mana pemilihan kelompok dipilih oleh dosen agar mahasiswa tidak memilih orang yang sesuai keinginannya. Wawancara juga dilakukan terhadap enam mahasiswa yang mewakili enam kelompok. Penelitian ini menggunakan metode kualitatif melalui observasi lapangan dan wawancana mendalam. Teknik pengumpulan data terhadap enam mahasiswa tersebut dilakukan melalui focus group discussion di ruang kelas Fakultas Komunikasi dan Bisnis, Telkom University pada 25 September 2017.

Selama melakukan observasi, penulis menggunakan pendekatan penetrasi sosial guna melihat sejauh mana mahasiswa melakukan komunikasi interpersonal. Penetrasi sosial menyediakan informasi yang lengkap untuk bisa menggambarkan perkembangan hubungan interpersonal dan sekaligus mengembangkannya dengan pengalaman individu sebagai sebuah proses pengungkapan diri yang mendorong kemajuan hubungan sehingga dapat menjadi pertimbangan dalam pengembangan hubungan (Devito, 1997: 242). Altman dan Taylor (dalam Wulandari, 2013: 104) menganalogikan penetrasi sosial seperti sebuah bawang, di mana individu dianggap seperti bawang yang mempunyai banyak lapisan. Lapisan 
kepribadian yang paling dalam adalah lapisan pribadi di mana terdapat nilai-nilai, konsep diri, emosional, dan lainnya. Sedangkan lapisan terluar adalah lapisan umum yang di mana baik diri sendiri ataupun orang lain dapat mengetahui secara langsung. Setelah lapisan luar terbuka kemudian mulai masuk ke lapisan yang lebih dalam lagi. Semakin dalam lapisan diri individu terbuka maka kemungkinan kesalahpahaman dalam berkomunikasi akan semakin jauh berkurang. Ide pertukaran sosial adalah bahwa manusia membuat suatu keputusan berdasarkan prinsip biaya (cost) dan imbalan (reward). Manusia dalam memilih suatu keputusan memperhatikan keseimbangan antara biaya dan imbalan. Pada interaksi antarmanusia, prinsip inilahyang disebut dengan pertukaran sosial.

Dalam buku Pengantar Teori Komunikasi: Analisa dan Aplikasi, West dan Turner membagi penetrasi sosial menjadi 4 tahapan: (1) orientasi; (2) pertukaran penjajakan afektif; (3) pertukaran afektif; (4) pertukaran stabil. Keempat tahapan ini akan digunakan peneliti sebagai dasar analisis proses komunikasi interpersonal pada mahasiswa di kelas Produksi Film Dokumenter saat melakukan brainstorming ide dan pembuatan karya film.

Salah satu aspek penting dalam komunikasi interpersonal adalah berbicara tentang diri sendiri atau disebut juga dengan pengungkapan diri. Pengungkapan diri (self-disclosure) adalah sebuah cara memberitahukan informasi pribadi yang belum diketahui menjadi informasi yang diketahui atau proses membuat informasi pribadi diketahui orang lain (Jourard \& Lasakow, 1958: 91). Self-disclosure punya perbedaan bagi setiap individu berdasarkan 5 dimensi: (1) ukuran atau jumlah; (2) valensi; (3) kecermatan dan kejujuran; (4) tujuan dan maksud; dan (5) keintiman. Lima dimensi ini akan digunakan untuk melihat keterbukaan antarindividu, saling memahami, serta memiliki rasa percaya dan ketertarikan individu terhadap orang lain.

\section{HASIL DAN PEMBAHASAN}

Produksi film dokumenter adalah mata kuliah yang dipelajari pada semester tujuh (7) sehingga pada dasarnya mahasiswa sudah saling mengenal satu sama lainnya.

Secara keseluruhan, kelas ini mempunyai 14 pertemuan. Berdasarkan Rancangan Pembelajaran Semester (RPS), ada tiga bagian utama dalam perkuliahan: (1) pra-produksi yang disampaikan pada pertemuan pertama hingga ke-9; (2) produksi di lapangan pada pertemuan ke-10 hingga ke-12; (3) pascaproduksi pada pertemuan ke-13 dan ke-14. 


\section{Penetrasi Sosial}

Berdasarkan observasi yang dilakukan dari keenam kelompok, bila kita mengacu pada teori penetrasi sosial, ternyata ada beberapa mahasiswa yang terlihat masih pada tahap orientasi walaupun mereka sudah saling mengenal satu sama lainnya. Tahap orientasi merupakan tahap paling awal dalam berinteraksi dengan individu. Tahap ini dilakukan pada tingkat publik dan hanya sedikit hal tentang diri sendiri yang akan diketahui oleh lawan bicaranya. Pada tahap ini, pertanyaan yang dibuat biasanya hanya hal-hal yang bersifat klise dan merefleksikan aspek superfisial dari seorang individu. Hal ini terlihat di pertemuan ke-3, di mana proses brainstorming pertama kali dilakukan dan terlihat suasana diskusi dalam setiap kelompok terlihat kaku. Peneliti melihat adanya suasana saling menahan diri untuk mengeluarkan ide. Walaupun kemudian ada yang mencoba melontarkan ide, namun respon dari mahasiswa lain masih terbatas. Dalam keadaan seperti ini, peran dosen sangatlah penting untuk memecah suasana. Dosen mencoba menggali ide-ide dari salah satu mahasiswa, kemudian membahas dan memberikan kesempatan kepada mahasiswa lain untuk memberikan pendapatnya. Akhirnya suasana pun mulai mencair. Dalam teori interaksi sosial tahap orientasi, individu cenderung tidak mengevaluasi atau mengkritik karena takut adanya kemungkinan merusak interaksi. Ketakutan akan menyinggung perasaan individu yang lain dan belum terlalu memahami pemikiran masing-masing menguatkan ketakutan dalam tahapan ini. Namun, peneliti melihat hal lainnya, motif individu (mahasiswa) menahan diri untuk berinteraksi cenderung karena rasa takut jika ide yang disampaikan tidak diterima/ jelek menurut teman-temannya. Demikian juga dalam hal merespon ide-ide yang dilontarkan mahasiswa lain, beberapa individu terlihat masih menahan diri dalam merespon ide tersebut. Ketakutan atas pemikiran yang salah atau tidak sesuai dengan pemikiran individu lain menjadi alasan mengapa mereka tidak terlalu responsif dalam merespon ide-ide yang ada.

Selanjutnya, pada tahap kedua, yaitu pertukaran penjajakan afektif, terlihat individuindividu sudah mulai membuka diri. Tahap ini merupakan perluasan area publik dari diri dan terjadi ketika aspek-aspek dari kepribadian seorang individu mulai muncul. Dalam tahap ini, antarindividu terlihat mulai melakukan eksplorasi informasi berupa hal-hal yang disenangi. Pertukaran penjajakan afektif ini mulai melibatkan perilaku verbal dan nonverbal antarindividu. Selain itu, terdapat sedikit spontanitas dalam komunikasi, karena individu merasa mulai nyaman satu sama lain sehingga suasana mulai cair. Peneliti melihat tahapan ini muncul pada awal pertemuan ke 2 sesi brainstorming. Saling menyetujui ide masingmasing terlihat di awal pertemuan ini. Namun, arus branstorming masih terlihat 'adem'. Artinya, belum ada perdebatan dalam sesi ini. Jika ada individu yang tidak setuju/kurang setuju, hanya terlihat secara implisit saja, seperti dari ekspresi atau gesture. Secara verbal, individu yang tidak setuju dengan individu lain memilih untuk diam. 
Tahap pertukaran afektif merupakan lapisan ketiga yang ditandai dengan kedekatan cukup intim antarindividu. Tahapan ini ditandai dengan ciri komunikasi yang lebih spontan disertai dengan pengambilan keputusan secara cepat, bahkan tidak terlalu mempertimbangkan konsekuensi terhadap hubungan keseluruhan. Pada tahap ini, peneliti melihat adanya beberapa mahasiswa yang cenderung pasif dibanding yang lainnya. Namun, secara keseluruhan suasana yang terbangun pada tahap ini sudah terlihat di akhir pertemuan ke- 2 . Selain itu, komunikasi nonverbal sudah mulai muncul di antara individu sehingga brainstorming pun mulai dinamis. Pada pertemuan ke-2 di sesi brainstorming ini, individu telah melewati 2 tahapan sekaligus, yaitu pertukaran penjajakan afektif dan pertukaran afektif. Jadi, mereka telah saling mengenal dan antarindividu telah mengetahui karakter masing-masing walaupun tidak secara mendalam. Karena ide-ide dasar sudah disampaikan oleh masing-masing individu di pertemuan pertama, mereka sudah saling 'memetakan' kekuatan dan kelemahan masing-masing. Hal ini secara tidak langsung membantu membangun kepercayaan diri individu untuk melakukan penyesuaian pemikiran, ide, dan wawasan terkait hal-hal yang didiskusikan. Jeda waktu antara pertemuan ke-1 dan ke-2 selama satu minggu berdampak signifikan sehingga masing-masing individu sehingga memiliki kesempatan untuk melakukan eksplorasi atas ide awal yang telah dibahas di pertemuan pertama. Pada pertemuan ke-2 sesi brainstorming, mereka sudah saling memberi masukan dan sanggahan atas sebuah ide yang dirasa tidak sesuai dengan pemikirannya.

Tahap terakhir dari teori pertukaran sosial adalah pertukaran stabil. Tahap ini berhubungan dengan pengungkapan pemikiran, perasaan, dan perilaku secara terbuka yang mengakibatkan munculnya spontanitas dan keunikan hubungan yang tinggi. Dalam tahap ini, kedua individu berada dalam tingkat keintiman tinggi dan sinkron. Pada tahap pertukaran stabil ini juga komunikasi antara individu sudah efisien dan sedikit kemungkinan adanya kesalahpahaman dalam berkomunikasi. Suasana ini sudah terlihat pada pertemuan ke-3 sesi brainstorming. Hampir semua individu sudah sangat menikmati diskusi. Mereka saling menimpali dengan cepat, saling merespon dan berani menyangkal jika ide salah satu dari individu dianggap tidak sesuai dengan pemikirannya. Pada pertemuan ketiga sesi brainstorming ini, suasana diskusi sudang sangat cair dan dinamis. Namun demikian, suasana yang terjadi bertolak belakang dengan pertemuan pertama. Dalam pertemuan ketiga ini, tercipta suasana keintiman yang kemudian berbaur dengan spontanitas. Namun dominasi dari beberapa individu dalam melakukan brainstorming mulai terlihat. Dari enam kelompok, ada satu atau dua individu di setiap kelompok yang muncul layaknya seorang leader dan selalu mendominasi diskusi. Ternyata mereka adalah anggota IKOM Chanel, salah satu unit kegiatan mahasiswa pada bidang film dan televisi yang ada di bawah Program Studi Ilmu Komunikasi Universitas Telkom. Mereka rata-rata sudah bergabung dengan unit kegiatan tersebut selama satu atau 
dua tahun sebelumnya sehingga mempunyai pengalaman memproduksi film atau program televisi dibanding mahasiswa yang tak mengikuti unit kegiatan tersebut.

\section{Self-Disclosure}

Salah satu aspek yang penting di dalam komunikasi interpersonal adalah berbicara tentang diri sendiri atau disebut juga dengan pengungkapan diri. Pengungkapan diri (self-disclosure) adalah sebuah cara memberitahukan informasi pribadi yang belum diketahui menjadi informasi yang diketahui atau proses membuat informasi pribadi diketahui oleh orang lain (Jourard \& Lasakow, 1958; Jourard \& Richman, 1963; Kadarsih, 2009; Permanasari, 2014; Ifdil dan Ardi, 2013; Desiningrum dan Galuh, 2016; Lazowski \& Andersen, 1990; Broder, 1987; Wijaya, 2013; Wahyuni \& Radjito, 2017).

Self-disclosure sendiri menjadi salah satu faktor yang cukup penting dalam menentukan keberhasilan di dalam interaksi sosial. Keberhasilan itu dapat dimulai dari keterbukaan antarindividu, berusaha saling memahami serta mempunyai rasa percaya dan ketertarikan individu terhadap orang lain.

Pada penelitian ini, peneliti melakukan pembagian terhadap dua kelompok mahasiswa, yaitu kelompok mahasiswa yang cenderung kurang aktif (pasif) dalam diskusi (memilih 3 mahasiswa dari kelompok 1-3) dan kelompok mahasiswa yang mendominasi (aktif) dalam proses diskusi (memilih 3 mahasiswa dari kelompok 4-6). Dalam konteks ini, peneliti ingin menggali lebih dalam lagi tentang apa yang dirasakan oleh mahasiswa tersebut pada saat melakukan proses brainstorming di kelompok mereka masing-masing.

Dari kelompok pasif, berdasarkan dimensi ukuran serta jumlah (frekuensi melakukan self-disclosure dan durasi pengembangan hubungan) dan valensi (hal positif atau negatif dari penyingkapan diri) ketiga individu dari kelompok pasif ini merasa masih harus melihat perkembangan diskusi dan mencoba memahami jalan pikiran individu yang lainnya. Adinda Giani, yang menjadi anggota kelompok ini, menyatakan bahwa ia merasa bingung di awalawal diskusi dengan apa yang harus disampaikan. Karena belum ada ide untuk dilontarkan, ia memilih diam dan lebih memperhatikan ide-ide yang dilontarkan oleh individu lainnya. Irene dan Guntur, sebagai informan kedua dan ketiga, menyampaikan hal yang sama. Pada dimensi ketepatan dan kejujuran (ketepatan dari pengungkapan diri individu yang dibatasi oleh suatu tingkatan di mana individu mengetahui dirinya sendiri), dimensi tujuan dan maksud (individu akan menyingkapkan apa yang ditujukan untuk diungkapan sehingga dapat mengontrol self-disclosure) dan dimensi keintiman (individu dapat menyingkapkan hal-hal intim dalam hidupnya atau hal yang dianggap impersonal), mereka merasakannya di pertemuan kedua. Tetapi, mereka sudah dapat mengikuti proses diskusi dan sudah tahu apa 
yang ada dalam pikiran mereka, namun mereka cenderung tidak mengungkapkannya. Menurut Adinda, Irene, dan Guntur, mereka mengetahui jika di dalam kelompoknya ada mahasiswa yang telah ikut bergabung dalam unit kegiatan film dan televisi. Mereka merasa apabila mahasiswa tersebut lebih mahir dalam memproduksi sebuah film. Oleh karena itu, apa yang dikatakan oleh mereka selama diskusi berjalan, diamini sepenuhnya oleh Adinda, Irene, dan Guntur.

Dari kelompok aktif, ada Dini, Fauzan, dan Rizky yang menjadi informan. Pada dimensi yang pertama (ukuran dan jumlah) dan kedua (valensi), apa yang dirasakan hampir sama dengan informan kelompok pasif. Mereka juga merasa masih harus melihat perkembangan diskusi dan mencoba untuk memahami jalan pikiran individu lainnya. Namun, hasil dari wawancara dengan ketiganya, mereka menyatakan bahwa sebenarnya mereka sudah memiliki gambaran ide-ide untuk disampaikan, namun dalam pertemuan pertama ide-ide tersebut masih disimpan. Sementara pada dimensi ketiga (ketepatan dan kejujuran), dimensi keempat (tujuan dan maksud), dan dimensi kelima (keintiman) ketiganya mulai berani menyatakan pemikiran-pemikiran mereka. Mereka melihat mahasiswa lain terlalu lama dalam berpikit sehingga ketiga informan ini mengambil inisiatif untuk melontarkan ide-ide dan memberikan gambaran mengenai proses produksi yang harus dilakukan. Peneliti melihat bahwa experience selama mengikuti unit kegiatan film dan televisi sangat membantu mereka untuk percaya diri dalam menyampaikan pemikirannya. Jika ada pertanyaan dari mahasiswa lain tentang ide-ide mereka, ketiganya dapat memberikan solusi akan permasalahan yang akan dihadapi. Pengalaman membuat film dan program televisi di unit kegiatan mahasiswa membuat ketiga informan ini memiliki pengetahuan serta pengalaman terkait dengan faktorfaktor teknis di lapangan yang harus diantisipasi pada saat produksi film dokumenter. Sehingga, mahasiswa yang lain memiliki kecenderungan untuk mengikuti dan membenarkan apa yang disampaikan oleh ketiga informan ini.

\section{KESIMPULAN}

Berdasarkan teori penetrasi sosial setiap individu memiliki sikap yang sama, yaitu wait and see pada tahap orientasi. Meskipun mereka sudah saling mengenal, tetapi tetap saja mereka saling menunggu dan melihat perkembangan diskusi. Pertemuan pertama menjadi ajang saling melakukan penjajakan atas pemikiran satu sama lain. Akan tetapi, hal itu hanya terjadi dalam pertemuan pertama di sesi brainstorming. Pada pertemuan yang ke-2, tahapan pertukaran penjajakan afektif dan pertukaran afektif sudah dapat dilakukan. Diskusi sudah mulai terlihat dinamis dan 'jual-beli' ide pun sudah mulai berjalan. Dalam pertemuan ke-3 di 
sesi brainstorming, tahap pertukaran stabil sudah muncul. Bahkan, sudah terlihat dominasi individu dalam setiap kelompok.

Dalam memilih kelompok untuk mengerjakan tugas kelas, dosen haruslah memperhatikan faktor kemampuan masing-masing individu. Hal ini adalah bagian dari strategi supaya setiap kelompok dapat belajar dari mahasiswa yang memiliki kemampuan lebih pada bidang tertentu. Tentunya, strategi ini tidak berlaku untuk semua mata kuliah. Menurut hemat peneliti, strategi ini dapat diberlakukan untuk mata kuliah yang membutuhkan praktik serta menuntut keahlian spesifik. Tidak dapat dipungkiri, setiap mahasiswa memiliki kemampuan di bidang yang berbeda. Dalam memproduksi sebuah film dokumenter, pembuat film dituntut agar memiliki kemampuan atau skill di berbagai bidang mulai dari kemampuan nonteknis hingga kemampuan teknis. Tuntutan kemampuan pada berbagai bidang inilah yang harus diperhatikan dosen pengampu mata kuliah pada waktu membagi kelompok. Ada mahasiswa yang mempunyai kemampuan di bidang kreatif, sementara yang lain memiliki kemampuan di bidang teknis. Mahasiswa yang mempunyai kemampuan lebih di bidangnya, cenderung akan lebih percaya diri menyatakan pemikirannya, dan ini bisa menjadi hal yang positif, di mana nantinya akan memberikan stimulan kepada mahasiswa lain dalam menyelesaikan tugas mereka.

\section{REFERENSI}

Abubakar, Fauzi. (2015). “Pengaruh Komunikasi Interpersonal antara Dosen dan Mahasiswa terhadap Motivasi Belajar dan Prestasi Akademik Mahasiswa". Jurnal Pekommas, 18(1): 53-62.

Broder, S.N. (1987). "Helping Students with Self-Disclosure”. School Couseor, 34(3).

Devito, Joseph A. (1997). Komunikasi Antarmanusia. Jakarta: Professional Books.

Galuh, A. dan Dinie R. Desiningrum. (2016). “Hubungan antara Dukungan Sosial Guru dengan Pengungkapan Diri (Self Disclosure) pada Remaja". Jurnal Empati, 5(4), 640-644.

Ifdil, Ifdil dan Zadrian Ardi. (2013). "Konsep Dasar Self Disclosure dan Pentingnya Bagi Mahasiswa Bimbingan dan Konseling". Pedagogi: Jurnal Ilmu Pendidikan, 13(1): 110118.

Jonathan, Christianto Donny. (2014). “Proses Komunikasi Interpersonal antara Pelatih dengan Kapten Tim Persebaya 1927". Jurnal e-Komunikasi, 2(1): 1-10.

Jourard, Sidney M. and Patricia Richman. (1963). "Factors in The Self-disclosure Inputs of College Students". Merrill-Palmer Quarterly of Behavior and Development, 9(2): 141148. 
Jourard, Sidney M. and Paul Lasakow. (1958). "Some Factors in Self-disclosure". The Journal of Abnormal and Social Psychology, 56(1): 91-98.

Kadarsih, Ristiana. (2009). "Teori Penetrasi Sosial dan Hubungan Interpersonal". Jurnal Dakwah, Media Komunikasi dan Dakwah, 10(1): 53-66.

Kamaruzzaman. (2016). “Analisis Keterampilan Komunikasi Interpersonal Siswa”. Jurnal Konseling Gusjigang, 2(2): 202-210.

Lazowski, L.E. and S.M. Andersen. (1990). "Self-Disclosure and Social Perception: The Impact of Private, Negative and Extreme Communications". Journal of Social Behavior and Personality, 5(2).

Permanasari, Risa. (2014). “Proses Komunikasi Interpersonal berdasarkan Teori Penetrasi Sosial (Studi Deskriptif Kualitatif Proses Komunikasi Interpersonal antara Personal Trainer dengan Pelanggan di Club House Casa Grande Fitness Center)". Jurnal IImu Komunikasi. Prasetyo, Hendri dan Tri Yuniati. (2014). "Pengaruh Gaya Kepemimpinan dan Komunikasi Interpersonal terhadap Semangat Kerja Karyawan". Jurnal IImu \& Riset Manajemen, 3(1): 1-17.

Pratiwi, Heppy Atma dan Endang Wiyanti. (2017). “Pola Komunikasi Interpersonal dalam Proses Bimbingan Skripsi". Dialektika: Jurnal Bahasa, Sastra, dan Pendidikan Bahasa dan Sastra Indonesia, 4(1): 85-99.

Pratiwi, Srie Wahyuni dan Dina Sukma. (2013). "Komunikasi Interpersonal Antar Siswa di Sekolah dan Implikasinya terhadap Pelayanan Bimbingan dan Konseling". Konselor (Jurnal Ilmiah Konseling), 2(1): 324-329.

Purnomo, Dinar Permadi dan Harmiyanto. (2016). "Hubungan Keterampilan Komunikasi Interpersonal dan Kepercayaan Diri Siswa Kelas X SMAN 1 Garum Kabupaten Blitar". Jurnal Kajian Bimbingan dan Konseling, 1(2): 55-59.

Siburian, P. (2014). “Hubungan Komunikasi Interpersonal dan Motivasi Belajar dengan Prestasi Belajar Penelitian Pengajaran". Jurnal Generasi Kampus, 7(1): 18-29.

Siska, Sudardjo dan Esti Hayu Purnamaningsih. (2003). "Kepercayaan Diri dan Kecemasan Komunikasi Interpersonal pada Mahasiswa." Jurnal Psikologi, 30(2): 67-71.

Wahyuni, Lussy Dwiutami dan Radjito. (2017). "Dukungan Sosial dan Pengungkapan Diri pada Peserta Didik Program Kesetaraan PAKET B". Jurnal Penelitian dan Pengukuran Psikologi, 6(1): 7-16.

Wijaya, Ida Suryani. (2013). "Komunikasi Interpersonal dan Iklim Komunikasi dalam Organisasi". Jurnal Dakwah Tabligh, 14(1): 115-126.

Wulandari, Tine Agustin. (2013). "Memahami Pengembangan Hubungan Antarpribadi melalui Teori Penetrasi Sosial". Jurnal Majalah IImiah UNIKOM, 11(1): 103-.110. 
